\title{
Cellular metabolic response to DNA damage
}

\author{
Seung Min Jeong ${ }^{*}$, Marcia C Haigis \\ From Metabolism, diet and disease \\ Washington, DC, USA. 29-31 May 2012
}

DNA damage elicits a cellular signaling response that initiates cell cycle arrest and DNA repair. The metabolic response to DNA damage is largely unknown. Here we report a novel metabolic response to genotoxic stress. DNA damage triggers a critical block in the uptake of glutamine, a mitochondrial substrate essential for cellular proliferation. Sirtuins regulate both cellular metabolism and stress responses. We found mitochondrial SIRT4 is involved in the metabolic response to DNA damage. These results suggest that the metabolic adaptation is important for cellular DNA damage response.

Published: 1 June 2012

doi:10.1186/1753-6561-6-S3-P24

Cite this article as: Jeong and Haigis: Cellular metabolic response to DNA damage. BMC Proceedings 2012 6(Suppl 3):P24.

Submit your next manuscript to BioMed Central and take full advantage of:

- Convenient online submission

- Thorough peer review

- No space constraints or color figure charges

- Immediate publication on acceptance

- Inclusion in PubMed, CAS, Scopus and Google Scholar

- Research which is freely available for redistribution 